\title{
A comparison of the availability and affordability of a market basket in two communities in the Chicago area
}

\author{
Daniel Block ${ }^{1, *}$ and Joanne Kouba ${ }^{2}$ \\ 'Department of Geography, Sociology, Economics, and Anthropology, Chicago State University, 9501 South King \\ Drive, Chicago, IL 60628, USA: ${ }^{2}$ School of Nursing at Loyola University Chicago, Chicago, IL, USA
}

Submitted 16 March 2005: Accepted 12 December 2005

\begin{abstract}
Objective: The purpose of the present study was to characterise the food landscape of an inner city African American neighbourhood and its mixed-race suburban neighbour. Detailed analysis focuses on the relationship between community store mix and price, availability and produce quality.

Design: A market basket study was completed by members of the Chicago Food Systems Collaborative. The US Department of Agriculture's standard market basket survey and methodology were used. Additional items and analyses were added in consultation with community members.

Setting: Austin is a lower-middle-class African American community of 117500 on the western edge of Chicago. Oak Park, which borders Austin, is an upper-middleincome suburb of 52500 with a mixed racial profile.

Subjects: A market basket survey of every retail food store in Austin and Oak Park was completed. A total of 134 were included.

Results: Results indicate that Austin has many grocery stores and few supermarkets. Many Austin groceries stores carry produce that is usually competitively priced, but often of unacceptable quality. Supermarkets had the best selection. Prices were lowest at discount supermarkets. Prices of packaged items were higher at independent stores than at chain supermarkets, but fresh items were cheaper.

Conclusions: Food access is related more to store type than number. In this study, item availability and produce quality varied greatly between store types. Price differences were complicated and varied by store type and food category. This has consequences in terms of food purchasing decisions and dietary quality that public health professionals should acknowledge.
\end{abstract}

Keywords Food access Food security Grocery stores Supermarkets Market basket
The access to quality, well-priced groceries in low-income areas has recently been identified as a factor in family and community food security ${ }^{1}$. According to the US Department of Agriculture (USDA), food insecurity is 'limited or uncertain availability of nutritionally adequate and safe foods or limited or uncertain ability to acquire acceptable food in socially acceptable ways' ${ }^{2}$. Hunger is 'the uneasy or painful sensation caused by a lack of food' or 'the recurrent and involuntary lack of access to food'. In 2002, $11.1 \%$ of US households experienced food insecurity ${ }^{3}$. Moderate hunger was reported by $28 \%$ of food-insecure and $3.3 \%$ of all households ${ }^{4}$.

In low-income families, food insecurity and hunger are associated with single-parent households, lack of health insurance and low educational attainment ${ }^{5}$. It is estimated that the combination of poor diet and inactivity is the second leading cause of death in the USA ${ }^{6}$. Factors including household income, school food and access to supermarkets are increasingly being examined in the relationship between food and health ${ }^{7}$. The present paper addresses the relationship between the local food environment and food access by examining the retail food landscape of a Chicago neighbourhood.

\section{Background}

\section{Impact of food insecurity and bunger on bealtb}

The paradox of hunger and obesity in low-income populations was suggested by Dietz ${ }^{8}$. In women and children, food insecurity is associated with increased prevalence of obesity ${ }^{9-12}$. Food insecurity and hunger have been linked to other adverse outcomes. Among food-insecure children, these include lower fruit consumption, higher cholesterol intake, headaches, colds, repeated grades and behavioural problems ${ }^{13-15}$. Dietary quality has been found to be lower in food-insecure women due to lower intakes of fruit, vegetables and milk, and less varied diets ${ }^{10}$. Focus groups with limited-resource individuals identified resourceful and harmful coping 
strategies including gardening, coupons, purchasing dented cans, shoplifting, diluting and limiting variety ${ }^{16}$.

\section{Possible explanations}

Several reasons have been proposed for these associations. Households need to spend available dollars on housing, utilities or health care. This leaves inadequate money for food. Low-cost foods tend to be energy-dense and palatable ${ }^{5}$. Faced with this dilemma, decision-makers serve low-cost foods to satisfy energy needs ${ }^{10}$. Overconsumption is easy to achieve, can be habitual and may lead to obesity ${ }^{5}$. This coupled with limited opportunity for physical activity enhances the likelihood of obesity in lowincome, food-insecure individuals, families and communities.

This relationship is a concern when coupled with knowledge of food consumption and physical inactivity patterns. Rolls et al. have demonstrated that volume is an important factor in regulating food intake ${ }^{17}$. A consistent pattern of palatable, energy-dense foods has been found to result in reduced satiety and overconsumption. Conversely, foods that are not energy-dense (such as fruits, vegetables) contain more water and less calories, fat and sugar. In the USA, these are comparatively expensive. Drewnowski and Specter calculated that the energy content of cookies was $1200 \mathrm{kcal} / \$$; but fresh carrots was $250 \mathrm{kcal} / \$^{5}$. Sugars, oils, refined grains and foods with longer shelf-life tend to be lower in cost and higher in energy. Nutrition educators often encourage consumption of less energy-dense foods, such as raw vegetables. The cost and availability of these foods must be evaluated.

Another factor gaining interest in public health efforts is community food access. The term 'food desert' has been used to characterise areas with minimal retail food stores in the $\mathrm{UK}^{18}$. Studies of the relationship between food deserts and both food costs and intake have produced inconsistent results ${ }^{18-20}$. In Minneapolis, Chung and Myers found that supermarkets, which offer lower prices, are concentrated in suburban areas while costlier small and non-chain stores are more likely to be in inner-city areas $^{21}$. In Los Angeles, Sloane et al. reported significantly lower availability of fresh fruits and vegetables in lowercompared with higher-income areas. However, availability of meat, poultry and fish was similar in all areas ${ }^{22}$. An analysis of food and prices comparing rural, suburban and urban New York locations found significant price differences between store types and regions ${ }^{23}$.

The absence of a variety of reasonably priced foods of acceptable quality can be a barrier to optimal diet patterns. This may be particularly true for people with transportation barriers or time limitations. Using data from the Atherosclerosis Risk in Communities study, Morland et al. found that supermarkets were less available to African Americans than white study participants. In addition, for every additional supermarket in their census tract, the fruit and vegetable intake of African Americans increased by
$32 \%$, suggesting that the local food environment is important in adherence to dietary recommendations ${ }^{1}$.

\section{Methodology}

The present study is the product of The Chicago Food Systems Collaborative, a community-university partnership. This group of community activists and academics, sponsored by the Kellogg Foundation, is working to improve access to healthy food on Chicago's West Side, primarily in the Austin community. The ultimate goal of the project is to found a community-owned store that provides quality foods at competitive prices. Working towards this goal, this study was conducted among all the retail food stores in Austin and Oak Park to discover the characteristics of the food 'landscape'.

By including every retail food outlet in the area, emphasis was placed on the differences between store types, and in particular whether the small neighbourhood groceries prevalent in Austin provide adequate food access to the neighbourhood. Including all stores also means that standard significance testing methods such as $t$-tests that apply to random samples must be used with care.

\section{Austin and Oak Park}

Austin is a community of 117527 inhabitants on the western edge of Chicago. It has a primarily African American population. Income levels are mixed, but Austin averages lower middle income with $24 \%$ of the households below the poverty level and a median household income in 2000 of \$US 33663. It also features a large percentage of long-term residents, with $42 \%$ of the households having lived in their homes for at least 10 years. Moreover, it has high rates of crime and health problems, and a high infant mortality rate ${ }^{24}$.

Austin's neighbouring community of Oak Park was also included in the study. Oak Park is an upper-middleincome suburb with a mixed profile and a population of 52500. Its median household income in 2000, \$US 59183 , was much higher than in Austin ${ }^{25}$. Oak Park is important both as a comparison and because, for many people living in Austin, the nearest supermarket is in Oak Park.

\section{Developing the market basket list and collecting the data}

The USDA Community Food Assessment Handbook guided the data collection, in addition to discussions with community members ${ }^{26}$. A list of 158 stores was compiled from data purchased from InfoUSA (a data vendor) coupled with geographical surveillance. The total numbers of stores surveyed was 134 . There were 24 stores that were not open for business when surveys were attempted, carried no food on the list (gas stations or liquor stores) or refused entry (3).

The food list was based on a USDA handbook list built from the USDA's Thrifty Food Plan recipes. This list does 
not include many items that are culturally important in the Austin community. To address this, the list was augmented through consultation with community members in the collaborative. Examples of food items added are greens, sweet potatoes and baby formula. So the results could be duplicated elsewhere, no foods from the USDA survey were removed. Questions were also added on the quality of the produce. Quality rating is extremely subjective, so quality classes were limited to two: 'satisfactory' or 'poor'. 'Poor' was defined as produce that was truly unacceptable due to evidence of rotting such as mould, soft dark flesh or slime. Team partners needed to agree on quality category.

The surveys took place in February and March 2003 on three Fridays in the morning and early afternoon. Friday was chosen as a day in which stores would be well stocked. The time of day was chosen for convenience to the surveyors and to avoid the after-school rush. Surveys were performed by eight teams, each having one student and one community member. The community members were recruited through a local collaborative partner. This approach brought a combination of academic and community-based knowledge to the teams that resulted in few refusals by stores and shared learning among the researchers and the community members ${ }^{22}$.

The teams were assigned stores of various types in dispersed locations to minimise the effect of team difference on the data. The survey listed foods with a desired common size to assess. Assessment included availability, cost and produce quality. The most common size was used to avoid pricing standard size items versus 'jumbo' sizes that may have limited availability and would be difficult to transport without a car. For each food, surveyors recorded the price of the cheapest item available in the size that most closely matched the specifications. Teams went through a six-hour training prior to the start of data collection, which included an interactive class, a practice session at a local supermarket, and a reaction period in which questions were answered.

Data were summarised by community and store type. There were 10 store types: national and regional chain supermarkets (such as Jewel); discount chain supermarkets (such as Aldi); independent supermarkets; independent groceries ('corner stores'); chain drug stores (such as Walgreen's); gas stations; liquor stores with food; chain convenience stores (such as Seven Eleven); dollar stores; and specialty stores (such as bakeries). Groceries were defined as food stores having an annual sales of \$US 2.5 million or below. This is based on the industry definition of \$US 2 million and our available sales data, which placed the break at \$US 2.5 million $^{27}$. When no sales data were available, the store was classified by comparing it with stores of similar floor size and product lines. Sales was used for classification rather than floor area following both US industry norms and because, in an urban context, many stores with smaller floor areas are densely packed with food and operate in the community more like supermarkets than corner groceries.

Due to the variance in the mix of store types between the two communities, much of the focus of the study was placed on the characteristics of the different store types. Stores were analysed by item availability, price and quality of produce. Availability was calculated by store type and product category. Quality data were collected only for produce and were summarised by store type.

Price calculations were completed utilising two techniques. First, prices for the USDA portion of the market basket were calculated using directions from the USDA handbook $^{27}$. Following this method, in cases where a store did not carry a food, the mean price for that item at all community stores was used. This was done so the total market basket cost could be estimated for each individual store. This could bias the results, especially for stores carrying less than $50 \%$ of the total items. The 'total market basket price' thus should truly be used only for general comparison, except in cases where the store carries almost all of the items, primarily the supermarkets. The total price calculations did not include the community-added items. Two store types, dollar and specialty, were eliminated from calculations owing to their low number of items carried.

Due to the limitations of the market basket price technique and the inability of this method to highlight pricing differences for particular food items, prices for each food item were also compared. In this analysis, the mean price of each food item carried by at least two stores within a particular store type was compared with the mean price at the four chain supermarkets. Tables were created for each class of products (produce, grains, etc.) showing whether items were generally cheaper or more expensive at each store type than at chain supermarkets. This analysis allows us to study price patterns in items of particular interest, such as fresh produce. If zero or one store carried an item within a store type, this item was taken out of the analysis and appears as 'No data'. Dollar stores, gas stations and specialty stores are not shown here due to the low number of items carried. Statistical analyses were conduced with the Statistical Package for the Social Sciences (SPSS), version 10.1 (SPSS, Inc., Chicago, IL, USA).

\section{Results}

As seen in Table 1, the most striking characteristic of the Austin retail food landscape when compared with Oak Park is its lack of chain supermarkets and the abundance of independent groceries and liquor stores with food. Counting all stores, Austin and Oak Park are served very similarly. Austin has one store for every 1237 residents, while Oak Park has one store for every 1347. However, the types of stores in the two communities are very different. For instance, Austin has one chain supermarket for its 117527 residents, while Oak Park has three, one for every 17508 residents. Austin has 50 independent groceries, one 
Table 1 Number of stores and population per store by store type and community

\begin{tabular}{|c|c|c|c|c|}
\hline \multirow[b]{2}{*}{ Store type } & \multicolumn{2}{|c|}{$\underset{\text { Austin }}{\text { (population }}=$} & \multicolumn{2}{|c|}{$\begin{array}{c}\text { Oak Park } \\
\text { (population }= \\
52524)\end{array}$} \\
\hline & Number & $\begin{array}{c}\text { Population } \\
\text { per store }\end{array}$ & Number & $\begin{array}{c}\text { Population } \\
\text { per store }\end{array}$ \\
\hline $\begin{array}{l}\text { Chain convenience } \\
\text { stores }\end{array}$ & 1 & 117527 & 4 & 13131 \\
\hline Chain drug stores & 6 & 19588 & 4 & 13131 \\
\hline Chain supermarkets & 1 & 117527 & 3 & 17508 \\
\hline Discount supermarkets & 2 & 58764 & 1 & 52524 \\
\hline Dollar stores & 4 & 29382 & 2 & 26262 \\
\hline Gas stations & 8 & 14691 & 7 & 7503 \\
\hline Independent groceries & 50 & 2351 & 4 & 13131 \\
\hline $\begin{array}{l}\text { Independent super- } \\
\text { markets }\end{array}$ & 3 & 39176 & 5 & 10505 \\
\hline Liquor stores with food & 19 & 6186 & 0 & NA \\
\hline Specialty stores & 1 & 117527 & 9 & 5836 \\
\hline Total & 95 & 1237 & 39 & 1347 \\
\hline
\end{tabular}

NA - not applicable.

for every 2351 residents, while Oak Park has just four, one for every 13131 residents.

When the independent groceries are mapped (Fig. 1), it becomes clear that almost every resident of Austin lives within half a mile $(\sim 0.8 \mathrm{~km})$ of a corner store. Most live within a quarter of a mile $(\sim 0.4 \mathrm{~km})$. Given this situation, the price, availability and quality of the food at these stores could greatly affect the food security of Austin residents. The importance of these independent groceries is emphasised when the location of supermarkets (chain, independent or discount) is mapped, with a quarter of a mile buffer, and overlain with data on the percentage of households in the area that have no car (Fig. 2). Just under half the population of Austin lives more than a quarter of a mile from a supermarket and in areas where more than $25 \%$ of the households do not have a car.

\section{Market basket price by community and store type}

As seen in Table 2, prices for the USDA market basket show that overall the mean price at Austin stores was 12 cents less than at Oak Park stores. This difference is significant in a simple difference of means $t$-test $(P<0.001)$. Some of the difference may arrive from the methodology of replacing missing values with the mean for all stores in that community. Using an analysis of variance, price differences also varied significantly by store type $(P<0.007)$. Within store types, the number of stores was too small to find significant differences between communities, but the chain supermarket in Austin had somewhat lower prices than the chains in Oak Park. There were also two discount supermarkets in Austin but only one in Oak Park. The independent groceries and supermarkets in Austin also had much lower mean prices than those in Oak Park.

Comparing store types, discount supermarkets were by far the cheapest, followed by independent supermarkets. Prices at chain supermarkets averaged somewhat lower than independents. Prices at independent groceries were somewhat higher. Chain convenience stores had the highest average prices of any group. Independent grocery prices in Oak Park were similar to chain convenience stores.

\section{Item availability}

Differences in store mix between Austin and Oak Park leads to a focus on availability, price and quality by store type. The mean number of items carried within each food category within each store type is seen in Table 3. Using analysis of variance, the effect of store type on availability was tested. Availability differed significantly by store type in all food categories and for the total market basket $(P<0.000)$. Within particular store types, the mean number of items carried was similar in Austin and Oak Park, so only the store type data are shown. Perhaps the most striking result is that chain supermarkets carried nearly all items. Independent supermarkets also carried most items, averaging 93 out of the 102. Discount supermarkets carried fewer items, a little more than $75 \%$. Only one of the three discount supermarkets carried greens and none carried sweet potatoes. Although it is hard to generalise with three stores, they do not seem responsive to local markets. Independent groceries carried a little more than half of the items. They tended to carry items with long shelf-lives. On average, these stores carried four of the 14 fresh fruits and vegetables surveyed. In produce, onions and potatoes were carried by $59 \%$ of the independent grocers, but only $44 \%$ carried more perishable tomatoes, the next highest item. Chain drug stores and convenience stores carried about half of the surveyed items. The other store classes carried less than $40 \%$.

\section{Quality of fresb produce}

While this study focused on the availability of a wide variety of foods as a measure of food access, special emphasis was put on the quality of fresh produce. Poorquality produce occurred only in two store types: independent groceries and liquor stores. All stores selling poor produce were in Austin. Of the 50 independent groceries in Austin, 32 (or 64\%) carried at least one produce item. Of these, 17 (or 53\%) carried at least one poor-quality item. Both of the liquor stores that carried fresh produce had at least one poor-quality item. Despite these results, many of the corner stores that carried the most produce carried none of poor quality. None of the six independent groceries that carried 10 or more produce items had any poor-quality items. Five of these were in Austin. Two particularly perishable items (green peppers and lettuce) were more likely than others to be of poor quality. Of the 17 independent groceries in Austin that carried lettuce, six were of poor quality.

\section{Price by food category and store type}

Due to the issues in calculating market baskets prices when many stores carry half or less of the items, price was 


\section{Oak Park \& Austin Independent Groceries}

\begin{tabular}{|c|c|c|}
\hline \multicolumn{3}{|c|}{$\begin{array}{c}\text { Percentage of populations near } \\
\text { independent groceries }\end{array}$} \\
\hline Total population & Oak Park & Austin \\
\hline$\%$ within $1 / 4$ mile & 16.9 & 117527 \\
\hline$\%$ within 1/2 mile & 60.8 & 92.7 \\
\hline$\%$ within 3/4 mile & 89.6 & 97.3 \\
\hline$\%$ within 1 mile & 99.1 & 98.7 \\
\hline
\end{tabular}

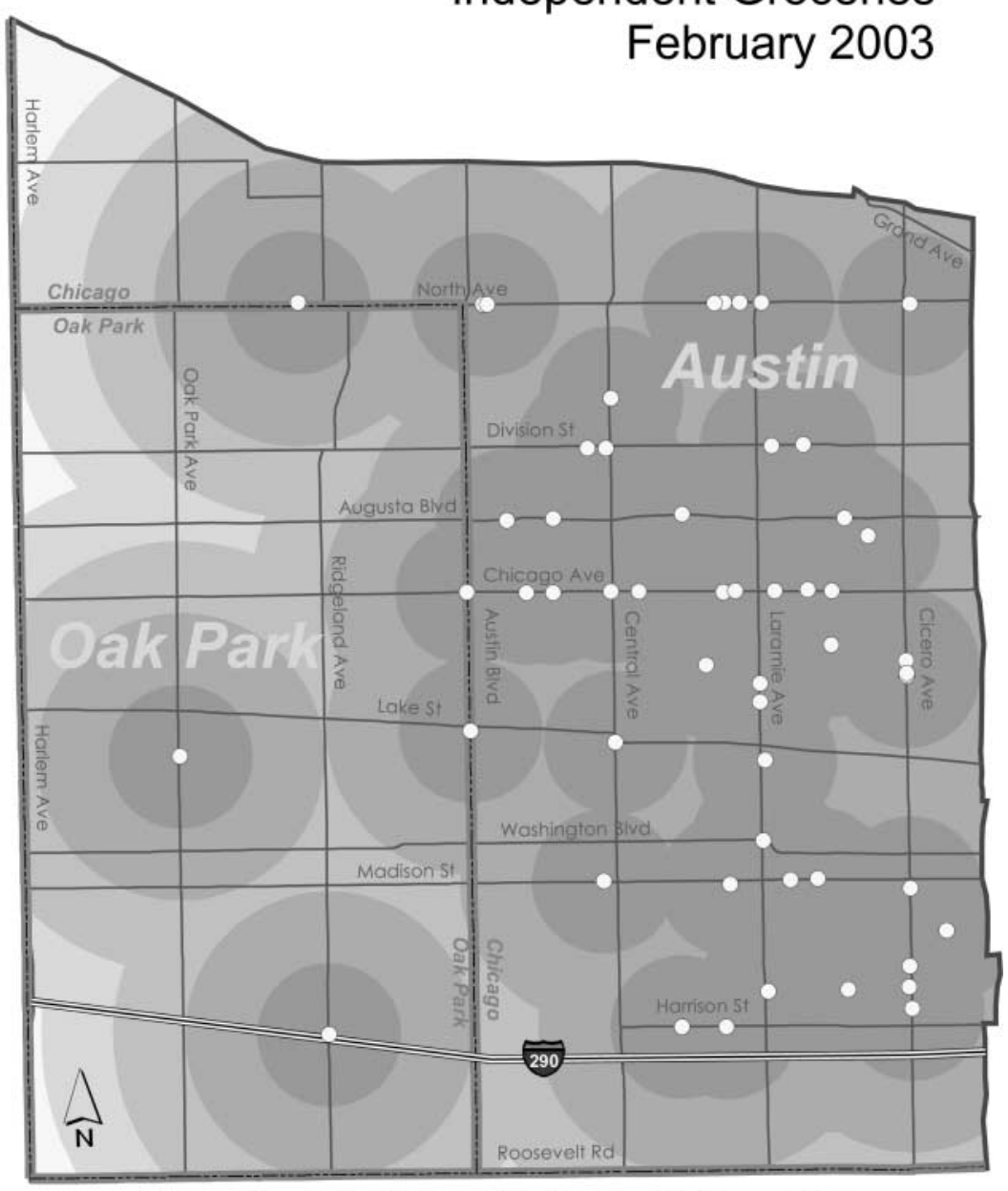

Sources: Chicago Food Systems Collaborative, 2000 Census, ESRI, ArcGIS StreetMap USA, and Northeastern Illinois Planning Commision Jan 2005 -Chicago State Univ. GIS Lab, Darrell Moore

Project Funded by W.K. Kellogg Foundation

Fig. 1 Most people in Austin are within walking distance of an independent grocery ('corner store'). This is not the case in Oak Park

compared for each food across stores, and then grouped by food category and store type. Table 4 shows how the mean prices of individual items in various food categories within a store type compared to the mean price of those items at chain supermarkets. For instance, when considering all items, the price at chain convenience stores was at least 10\% higher than at chain supermarkets for 48 of the items. Six items had similar prices, two were at least $10 \%$ cheaper, and 46 were available at no or one chain convenience store. Dollar stores, specialty stores and gas stations were left off the chart owing to their high numbers of missing items. Viewing the data for all 102 items studied, discount supermarkets were at least $10 \%$ cheaper than chain supermarkets for the vast majority of the items they carry.

The data become more interesting when viewed by product category. In particular, fresh produce and meat were generally cheaper at independent groceries and supermarkets than at chain supermarkets. Independent supermarkets were at least $10 \%$ cheaper than chains for 11 of the 12 fresh produce items calculated, while independent groceries were cheaper for nine of the 13 fresh produce items calculated (poor quality was often noted). The data were similar for fresh meats. All five fresh meat items were at least $10 \%$ cheaper at independent supermarkets than at chains and three of the four fresh meat items calculated were at least 10\% cheaper at independent groceries than at chain supermarkets. Discount supermarkets were cheaper than chains in all categories. For fresh produce, prices were also competitive at liquor stores and chain convenience stores, where four of the six items that had similar prices to chain supermarkets were fresh produce items.

Beyond the fresh meat and produce categories, chain supermarkets were generally cheaper than all other store types except discount supermarkets for all product 


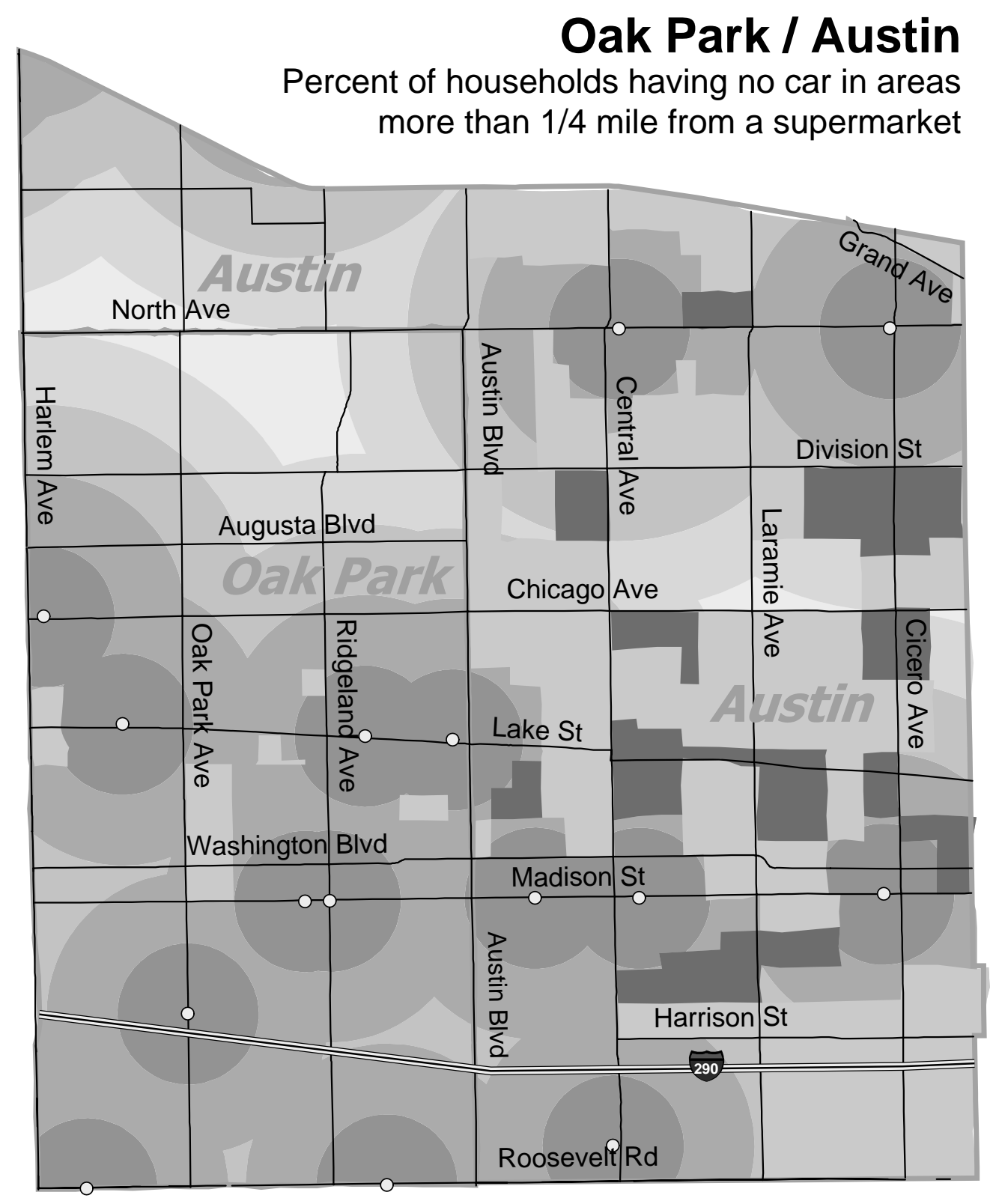

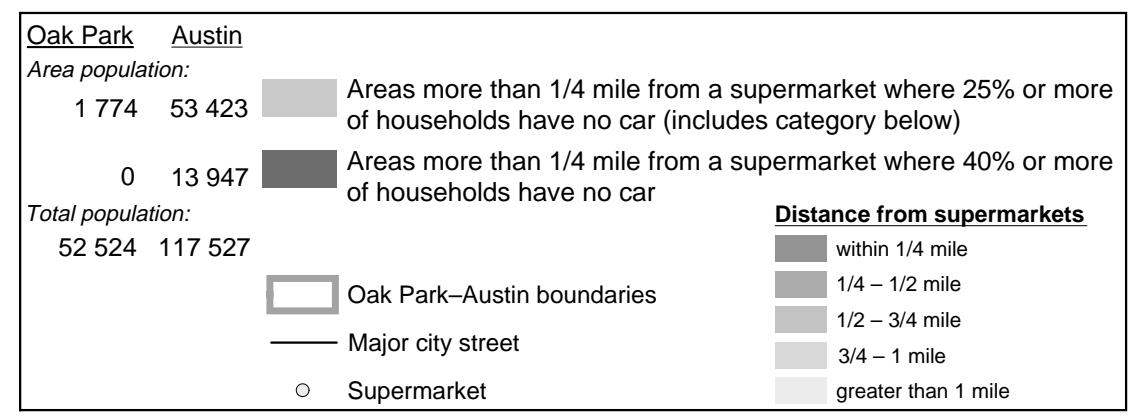

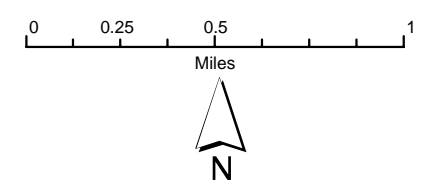

Sources: Chicago Food Systems Collaborative, 2000 Census, ESRI, ArcGIS StreetMap USA, and Northeastern Illinois Planning Commision May 2004 -Chicago State Univ. GIS Lab, Darrell Moore

Fig. 2 A large area of Austin, including almost half of Austin residents, is both further than a quarter of a mile to any supermarket and has at least $25 \%$ of households without a car

categories except spices, baking supplies and condiments. This is probably because other store types often carried less expensive brands. The 65 items not in these categories include dairy foods and shelf-stable items such as grains and canned products. For these remaining items, 42 were at least $10 \%$ more expensive at independent supermarkets and 48 were at least 10\% more expensive at independent groceries than chain supermarkets. 
Chicago market basket

Table 2 Mean price of market basket by community and store type*

\begin{tabular}{lcc}
\hline & \multicolumn{2}{c}{ Mean price (\$US) } \\
\cline { 2 - 3 } Store type† & Austin & Oak Park \\
\hline Chain convenience stores & 134 & 132 \\
Chain drug stores & 108 & 121 \\
Chain supermarkets & 91 & 116 \\
Discount supermarkets & 71 & 75 \\
Gas stations & 111 & 127 \\
Independent groceries & 113 & 132 \\
Independent supermarkets & 94 & 112 \\
Liquor stores with food $^{*}$ & 110 & NA \\
Total $^{*}$ & 110 & 122 \\
\hline
\end{tabular}

NA - not applicable.

* Price differs significantly between Austin and Oak Park at the $P<0.001$ level. Combining both communities, store type is a significant influence on price at the $P<0.007$ level. Significance testing was not performed between communities within store types due to low numbers of stores.

† Note that missing values were replaced by the mean of stores carrying that item in that community. This means that the mean price of an item in a community affects the price at all stores in that community. This may skew results in store types that carry low percentages of items, such as gas stations, and may account for some of the differences in price between the two communities.

\section{Discussion and conclusions}

The type and number of grocery stores differ strikingly between Austin and Oak Park. Austin has many more food stores than Oak Park, but most of these are small, independent groceries and liquor stores with low overall food availability, particularly of produce. While there were some independent grocery stores in Austin with acceptable produce, all poor-quality produce was found at independent grocery stores and liquor stores in Austin. In a focus group with local store owners, both logistical problems in obtaining fresh produce and issues with selling it before it spoils were cited to explain this pattern. If Austin residents had to rely only on grocery stores in the neighbourhood surrounding their homes, obtaining a wide variety of acceptable quality foods for an optimal diet would be difficult.

Food availability differences between the communities are determined by store mix. Chain supermarkets carried close to every item surveyed. Independent supermarkets also carried the vast majority of the items. Overall Austin, with approximately twice the number of residents as Oak Park, had just six supermarkets versus nine in Oak Park.

Price comparisons were complicated. Prices averaged lower in Austin than in Oak Park. By store type, discount supermarkets were by far the least expensive. However, these markets by their nature appeared to carry very generic items that often overlooked the communities' cultural preferences. By item, average prices of fresh produce and meat at independent groceries and supermarkets were lower than at chain supermarkets. Packaged items at the independent stores were overwhelmingly more expensive, except spices, condiments and baking supplies. 
Table 4 Average price of food items compared with average price of same items at chain supermarkets

\begin{tabular}{|c|c|c|c|c|c|c|}
\hline & $\begin{array}{c}\text { Chain convenience } \\
\text { stores (5) }\end{array}$ & $\begin{array}{l}\text { Chain drug stores } \\
(10)\end{array}$ & $\begin{array}{l}\text { Independent } \\
\text { groceries } \\
(54)\end{array}$ & $\begin{array}{c}\text { Liquor } \\
\text { stores } \\
\text { with food (19) }\end{array}$ & $\begin{array}{c}\text { Discount } \\
\text { supermarkets } \\
\text { (3) }\end{array}$ & $\begin{array}{c}\text { Independent } \\
\text { supermarkets } \\
\text { (8) }\end{array}$ \\
\hline \multicolumn{7}{|l|}{ All 102 Items } \\
\hline Price at least $10 \%$ higher & 48 & 42 & 57 & 44 & 1 & 49 \\
\hline Price similar & 6 & 10 & 11 & 13 & 2 & 22 \\
\hline Price at least $10 \%$ cheaper & 2 & 18 & 28 & 15 & 73 & 31 \\
\hline No data & 46 & 32 & 6 & 30 & 26 & 0 \\
\hline \multicolumn{7}{|l|}{ All 14 fresh produce Items } \\
\hline Price at least $10 \%$ higher & 4 & 1 & 2 & 0 & 0 & 1 \\
\hline Price similar & 4 & 0 & 2 & 1 & 1 & 0 \\
\hline Price at least $10 \%$ cheaper & 0 & 0 & 9 & 3 & 11 & 13 \\
\hline No data & 6 & 13 & 1 & 10 & 2 & 0 \\
\hline \multicolumn{7}{|l|}{ All five fresh meat items } \\
\hline Price at least $10 \%$ higher & 0 & 0 & 1 & 0 & 0 & 0 \\
\hline Price similar & 0 & 0 & 0 & 0 & 0 & 0 \\
\hline Price at least $10 \%$ cheaper & 0 & 0 & 3 & 1 & 3 & 5 \\
\hline No data & 5 & 5 & 1 & 4 & 2 & 0 \\
\hline \multicolumn{7}{|c|}{ All 18 spices, baking supplies and condiments } \\
\hline Price at least $10 \%$ higher & 6 & 4 & 6 & 5 & 1 & 6 \\
\hline Price similar & 1 & 0 & 0 & 5 & 0 & 5 \\
\hline Price at least $10 \%$ cheaper & 1 & 13 & 12 & 6 & 9 & 7 \\
\hline No data & 10 & 1 & 0 & 2 & 8 & 0 \\
\hline \multicolumn{7}{|l|}{ All 65 other items } \\
\hline Price at least $10 \%$ higher & 38 & 37 & 48 & 39 & 0 & 42 \\
\hline Price similar & 1 & 10 & 9 & 7 & 1 & 17 \\
\hline Price at least $10 \%$ cheaper & 1 & 5 & 4 & 5 & 50 & 6 \\
\hline No data & 25 & 13 & 4 & 14 & 14 & 0 \\
\hline
\end{tabular}

The news is not all bad for Austin. The independent groceries that dominate the area are within walking distance for most Austin residents and often have competitive prices for fresh items, if carried. However, quality and availability are suboptimal as are prices for most packaged items. Interestingly, in a set of subsequent focus groups with community residents and store managers, the best of these local stores appear to be used often to purchase fresh items, especially meat, while other purchases are made outside the community.

The methods and focus of this study were greatly influenced by community member involvement. In specific, the availability patterns of culturally appropriate foods would not have been identified without this input. This information has been used to begin local action in Austin to improve food access by the development of a community-owned grocery supermarket.

If food availability contributes to health through optimal dietary patterns, then Austin residents may experience difficulty attaining good-quality diets from within the community. While Austin residents can and do travel for groceries, limited availability within the community creates barriers for those without easy access to a car. Carrying groceries home by public transportation is difficult and often involves transfer at the city limit.

By studying only two communities, we cannot come to a general conclusion about the influence of race, class or urbanity on food access. Other limitations include the possibly low seasonal availability of produce during the study period. Judgements related to package size selection were sometimes difficult. The two-category quality measurement is also a limitation.

It is clear from this study that the mix of store types within a community makes a large difference to access to healthy foods. This study highlights the need to consider community food systems as another contributor to food insecurity. The ability of households to obtain foods contributes to optimal dietary patterns and the role that food systems may play in negative health outcomes such as obesity. While chain supermarkets and supercentres may be adequate for areas with high automobile access, in areas with lower access, a diversified store mix could be beneficial. In Austin, discount chains and the few highquality independent grocers meet particular needs of the residents. Even many of the 'corner stores' offer fresh produce at reasonable prices. This work highlights the need to match store mix to neighbourhood characteristics by those who advocate for public health policy, community groups and planners. Planning and health departments could work with stores to overcome barriers to higher produce quality and variety. While increasing the local market for produce may be difficult, community activists have discussed establishing a local wholesale network to minimise barriers to obtaining produce faced by individual stores.

\section{Acknowledgements}

This study was supported by a grant from the W.K. Kellogg Foundation. We must also thank the Westside 
Health Authority and executive director Jacqueline Reed for its assistance with the project. This study with designed in consultation with Claire Kohrman of Westside Health Authority, LaDonna Redmond of the Institute for Community Resource Development, and Maureen Hellwig of the Policy Research Action Group at Loyola University Chicago. Data collection was completed by D Block, J Kouba, C Kohrman, dietetic interns from Loyola University Chicago including G Cox, D Thomas, M Mroz, E Ryan, J Winland, and community members recruited by the West Side Health Authority including B Bell, G Cotton, M Hardnet, W Herriot, O Huntley, P Love, S Robinson, B Shelton and P Stewart. $\mathrm{S}$ Dircks, $\mathrm{H}$ Hickman, $\mathrm{H}$ Sewell and $\mathrm{J}$ Smith from Chicago State University also helped collect data and did data entry. D Moore produced the maps.

Human participant protection: Data were not collected from human study participants.

\section{References}

1 Morland K, Wing S, Diez Roux A. The contextual effect of the local food environment on residents' diets: The Arteriosclerosis Risk in Communities study. American Journal of Public Health 2002; 92: 1761-7.

2 Hamilton W, Cook J, Thompson W. Household Food Security in the United States: 1995-1998. Washington, DC: US Department of Agriculture, Food and Nutrition Service, 1997.

3 Economic Research Service. Briefing Room: Food Security in the United States [online]. Available at http://www.ers.usda. gov/Briefing/FoodSecurity. Accessed 16 August 2004.

4 Carlson SJ, Andrews MS, Bickel GW. Measuring food insecurity and hunger in the United States: development of a national benchmark measure and prevalence estimates. Journal of Nutrition 1999; 129: 510S-6S.

5 Drewnowski A, Specter SE. Poverty and obesity: the role of energy density and energy costs. American Journal of Clinical Nutrition 2004; 79: 6-16.

6 Mokdad AH, Marks JS, Stroup DF, Gerberding JL. Actual causes of death in the United States, 2000. Journal of the American Medical Association 2004; 291: 1238-45.

7 Vastag B. Obesity is now on everyone's plate. Journal of the American Medical Association 2004; 291: 1186-9.

8 Dietz WH. Does hunger cause obesity? Pediatrics 2004; 95: 766-7.

9 Basiotis PP, Lino M. Food insufficiency and prevalence of overweight among adult women. Nutrition Insights 1992; 26: $1-2$.

10 Alaimo K, Olson CM, Frongillo EA. Low family income and food insufficiency in relation to overweight in US children: is there a paradox? Archives of Pediatrics \& Adolescent Medicine 2001; 155: 1161-7.

11 Olson CM. Nutrition and health outcomes associated with food insecurity and hunger. Journal of Nutrition 1999; 129: $521 \mathrm{~S}-4 \mathrm{~S}$.
12 Townsend MS, Peerson J, Love B, Achterberg C, Murphy SP. Food insecurity is positively related to overweight in women. Journal of Nutrition 2001; 131: 1738-45.

13 Casey PH, Szeto K, Lensing S, Bogle M, Weber J. Children in food-insufficient, low-income families: prevalence, health and nutrition status. Archives of Pediatrics \& Adolescent Medicine 2001; 155: 508-14.

14 Alaimo K, Olson CM, Frongillo EA, Briefel RR. Food insufficiency, family income, and health in US preschool and school-aged children. American Journal of Public Health 2001; 91: 781-6.

15 Alaimo K, Olson CM, Frongillo EA. Food insufficiency and American school-aged children's cognitive, academic and psychosocial development. Pediatrics 2001; 108: 44-53.

16 Kempson K, Keenan DK, Sadani PS, Adler A. Maintaining food insufficiency: coping strategies identified by limitedresource individuals versus nutrition educators. Journal of Nutrition Education and Behavior 2003; 35: 179-89.

17 Rolls BJ, Castellanos VH, Halford JC. Volume of foods consumed affects satiety in men. American Journal of Clinical Nutrition 1998; 67: 1170-7.

18 Wrigley N. 'Food deserts' in British cities: policy context and research priorities. Urban Studies 2002; 39: 2029-40.

19 Cummins SCJ. The local food environment and health: some reflections from the United Kingdom. American Journal of Public Health 2003; 93: 51.

20 Kaufman PR, MacDonald JM, Lutz SM, Smallwood DM. Do the Poor Pay More for Food? Item Selection and Price Differences Affect Low-income Housebold Food Costs. Agricultural Economic Report No. 759. Washington, DC: Department of Agriculture, Food and Rural Economics Division, Economic Research Service, 1997.

21 Chung C, Myers SL. Do the poor pay more for food? An analysis of grocery stores availability and food price disparities. Journal of Consumer Affairs 1996; 33: 276-96.

22 Sloane DC, Diamant AL, Lewis LB, Yancey AK, Flynn G, Mascimento LM, et al. Improving the nutritional resource environment for healthy living through community-based participatory research. Journal of General Internal Medicine 2003; 18: 568-75.

23 Crockett EG, Clancy KL, Bowering J. Comparing the cost of a Thrifty Food Plan market basket in three areas of New York state. Journal of Nutrition Education and Behavior 1992; 24: 72S-9S.

24 Chicago Department of Health. Chicago Community Health Profile: Austin [online], 1 July 2004. Available at http://www. cityofchicago.org/Health/profiles. Accessed 10 September 2004.

25 US Census Bureau, Population Division, Decennial Programs Coordination Research Branch. 2000 Census of Population and Housing: Summary File 3 [online], 25 August 2002. Available at http://www.census.gov/ population/www/cen2000/SF3-housing.html. Accessed 17 August 2005.

26 Cohen B. Community Food Security Assessment Toolkit. E-FAN No. (O2-013) [online], July 2002. Available at http:// www.ers.usda.gov/Publications/efan02013/. Accessed October 2002.

27 Food Marketing Institute. Supermarket Facts: Industry Overview 2004 [online], 2004. Available at http://www.fmi. org/facts_figs/superfact.htm. Accessed 11 January 2005. 